\title{
Lethal effect of the dinoflagellate Heterocapsa circularisquama upon the tintinnid ciliate Favella taraikaensis
}

\author{
Takashi Kamiyama*, Satoshi Arima
}

Red Tide Research Division, Nansei National Fisheries Research Institute, 2-17-5, Ohno, Saeki, Hiroshima 739-04, Japan

\begin{abstract}
We examined the effect of the toxic dinoflagellate Heterocapsa circularisquama in bloom concentrations on the mortality process of the tintinnid ciliate Favella taraikaensis. The number of viable $F$. taraikaensis decreased during the first $7 \mathrm{~h}$ of the incubation experiment and disappeared within $24 \mathrm{~h}$ at a $H$. circularisquama concentration of $\geq 6.4 \times 10^{3}$ cells ml ${ }^{-1}$. Mortality of the ciliates occurred more rapidly with increasing concentrations of $H$. circularisquama. Morphological changes of $F$. taraikaensis cells, characterized by swollen and/or spherical forms, were observed after 4 and $7 \mathrm{~h}$ of incubation. Microscopic observations showed that $H$. circularisquama cells frequently adhered to the adoral membranelles of $F$. taraikaensis. The mean adhesion time of $H$. circularisquama cells to the adoral membranelles of $F$. taraikaensis was significantly longer than cells of the non-toxic dinoflagellate Heterocapsa triquetra. During the adhesion process. contact of $H$. circularisquama cells with the cytoplasm around the oral plug of $F$. taraikaensis was observed. Filtrate of $H$. circularisquama culture solution had no effect on the activity of $F$. taraikaensis cells. These results suggest that $H$. circularisquama causes physiological problems for F. taraikaensis through cell contact, with higher algal concentrations increasing the frequency of cell contact between $H$. circularisquama and $F$. taraikaensis. which may enhance the noxious effect of $H$. circularisquama on F. taraikaensis.
\end{abstract}

KEY WORDS: Heterocapsa circularisquama - Tintinnids · Ciliates - Favella taraikaensis - Growth inhibition - Cell contact

\section{INTRODUCTION}

Since first recorded in Uranouchi Bay in 1988, red tides of the dinoflagellate Heterocapsa circularisquama have caused mass mortality of pearl oysters and other bivalves, seriously damaging shellfish aquaculture and fisheries production in western Japan (Yamamoto \& Tanaka 1990, Matsuyama et al. 1995). This dinoflagellate specifically kills bivalves, probably due to the production of toxins which repress bivalve feeding (Matsuyama et al. 1995, 1997, Nagai et al 1996). Although its characteristics are not known in detail, the toxin is considered to be a protein-like substance localized on the cell surface (Matsuyama et al. 1997).

•E-mail: kamiyama@nnf.affrc.go.jp
Zooplankton reject some red-tide flagellates as food sources. Uye \& Takamatsu (1990) reported that calanoid copepods hardly feed on red-tide algae such as Gymnodinium mikimotoi or Heterosigma akashiwo. At least some tintinnid ciliates, an important component of microzooplankton, have a selective feeding ability (Stoecker et al. 1981) and can instantaneously reject $H$. akashiwo or Rhodomonas sp., which are poor food sources for tintinnids (Taniguchi \& Takeda 1988). Growth inhibition of the tintinnid species Favella ehrenbergii by Alexandrium tamarense (Hansen 1989) and Gyrodinium aureolum (Hansen 1995) has been recognized in culture experiments. Negative responses to harmful flagellates by tintinnids or rotifers are probably caused by cell surface chemical compounds (Verity \& Stoecker 1982, Egloff 1986) or toxic substances exuded from the algae (Hansen 1989, 1995). 
There has been only one study on the interactions between Heterocapsa circularisquama and zooplankton (Kamiyama 1997) which reported that the tintinnid Favella taraikaensis suffered mass mortality within a few days when the concentration of $H$. circularisquama exceeded ca $10^{3}$ cells $\mathrm{ml}^{-1}$, although the tintinnid ciliates $F$. azorica and F. taraikaensis actively fed on this alga at concentrations of less than $10^{3}$ cells $\mathrm{ml}^{-1}$. The mass mortality of $F$. taraikaensis indicates that $H$. circularisquama cells are specifically harmful to grazers under dense bloom conditions. Studies on the harmful effects of $H$. circularisquama are useful to elucidate the processes of bloom formation and decay in the coastal areas and to estimate the influence of a $\mathrm{H}$. circularisquama bloom on the function of microbial food webs in coastal marine systems.

Here, we examined the inhibition effects of Heterocapsa circularisquama cells at high concentrations on the tintinnid ciliate Favella taraikaensis and observed the interactions between them in detail.

\section{MATERIALS AND METHODS}

Culture of tintinnids and prey phytoplankton. Strains of Favella taraikaensis were isolated from either supernatant seawater on incubated sediment collected from Hiroshima Bay or seawaters in Gokasho Bay and Hiroshima Bay. These ciliates were grown in $200 \mathrm{ml}$ flasks with $150 \mathrm{ml}$ of culture medium consisting of filtered and autoclaved seawater enriched with $0.1 \mathrm{ml}$ $\mathrm{I}^{-1}$ of $\mathrm{f} / 2$ iron-EDTA trace metal solution (Stoecker et al. 1988). Heterocapsa triquetra only or a mixture of $H$. triquetra and Gymnodinium sp. at a total concentration in the order of magnitude of $10^{3}$ cells $\mathrm{ml}^{-1}$ were supplied as food. Portions of the culture with food algae were transferred to new medium every 4 to $5 \mathrm{~d}$ to maintain the cultures.

Heterocapsa circularisquama (cell dimensions $18.1 \times$ $12.4 \mu \mathrm{m}$ ) was isolated from Ago Bay in December 1992 , and Gymnodinium sp. (cell dimensions $10.6 \times 8.6 \mu \mathrm{m}$ ) and Heterocapsa triquetra (cell dimensions $23.0 \times$ $17.1 \mu \mathrm{m}$ ) were isolated from Hiroshima Bay in June 1986 and in April 1991, respectively. These cultures were maintained in $50 \mathrm{ml}$ culture flasks containing $25 \mathrm{ml}$ of $\mathrm{f} / 2$ medium (Guillard \& Ryther 1962).

Survival of Favella taraikaensis at high concentrations of Heterocapsa circularisquama. An experiment was conducted to study the effects on the survival of Favella taraikaensis at high concentrations of Heterocapsa circularisquama during short-term incubations. Five concentrations of $H$. circularisquama in the order of magnitude of $10^{3}$ to $10^{4}$ cells $\mathrm{ml}^{-1}$ were prepared as experimental treatments and a no food treatment was also made as a control. Two mililititers of each concen- tration were dispensed into 4 wells of multiple well plates (1.2 wells) and then 5 individuals of $F$ taraikaensis were inoculated into all wells. The plates were incubated at $20^{\circ} \mathrm{C}, 30 \mu \mathrm{mol}$ photon $\mathrm{m}^{-1} \mathrm{~s}^{-1}$ with a 14h:10h light-dark photo cycle. Motile individuals which were able to swim in each well were counted at 4,7, and 24 h of incubation with a stereomicroscope.

An identical experiment at a concentration of $2.86 \times$ $10^{4}$ cells $\mathrm{ml}^{-1}$ was repeated to observe in detail any morphological changes in Favella taraikaensis. Motile F. taraikaensis after 4 and 7 h of incubation were observed with an inverted epifluorescence microscope (Olympus IX70) attached to a VTR system (Ikegami time lapse video cassette recorder TVR-7480, Victor color video monitor TM-150S and Sony camera adapter CMA-D2). Using the film recorded before the incubation and after $4 \mathrm{~h}$ of incubation, the lateral cell area, representing the cell volume of $F$. taraikaensis, was measured using a high definition image processor (Nexus Inc. nexus 9000) to examine any morphological change of the F. taraikaensis cells.

Heterocapsa circularisquama uptake by Favella taraikaensis during short-term incubation. This experiment was designed to examine whether or not mortality of Favella taraikaensis is due to the avoidance of feeding on Heterocapsa circularisquama. Part of the supernatant water was removed without agitation from a culture strain of $F$. taraikaensis when the density of $F$. taraikaensis reached $>10$ ind. $\mathrm{ml}^{-1}$. Within this supernatant water, almost all the food algae were consumed and auto-fluorescence in the food vacuoles of $F$. taraikaensis due to food algae was hardly observed. Fifty milliliters of supernatant water was dispensed into each of three $100 \mathrm{ml}$ flasks. Culture of $H$. circularisquama was added to each flask at final concentrations of $5.2 \times 10^{2}, 5.2 \times 10^{3}$ and $1.35 \times 10^{4}$ cells $\mathrm{mI}^{-1}$, and then incubation immediately started under conditions of $20^{\circ} \mathrm{C}$ and $30 \mu \mathrm{mol}$ photon $\mathrm{m}^{-1} \mathrm{~s}^{-1}$. Before the addition of the alga and at $10,20,30,40,50,60$ min of incubation, 2 $\mathrm{ml}$ of culture was taken off from each flask and transferred into a well of multiple well plates (24 wells) containing $0.2 \mathrm{ml}$ of $20 \%$ buffered formaldehyde for fixation of the tintinnids. Auto-fluorescence particles inside food vacuoles of each $F$. taraikaensis were counted using an inverted epifluorescence microscope (DIAPHOT-TMD, Nikon). The average particle number of more than 20 individuals of $F$. taraikaensis at each time point was calculated for each treatment. The concentration of Heterocapsa triquetra cells carried over from the stock culture into the experimental medium was 12 cells $\mathrm{mll}^{-1}$, and the mean number of auto-fluorescence particles in the food vacuoles was 0.3 cells ind. ${ }^{-1}$ before the addition of $H$. circularisquama.

Effects of exudate from Heterocapsa circularisquama on the survival of Favella taraikaensis, The effect 
of dissolved substances released from Heterocapsa circularisquama on the survival of Favella taraikaensis was examined. Algal suspension $\left(1.37 \times 10^{5}\right.$ cells $\left.\mathrm{ml}^{-1}\right)$ was centrifuged $(1600 \times g, 10 \mathrm{~min})$ and then the supernatant was filtered with a $0.22 \mu \mathrm{m}$ pore-size filter (Millipore GV). The filtrate was used without dilution to prevent toxic substance from decomposing due to $\mathrm{pH}$ shift. The algal suspension and $f / 2$ medium (control) were diluted 4 times with the culture medium for the ciliates. Final concentration in the treatment of algal suspension was $3.42 \times 10^{4}$ cells $\mathrm{ml}^{-1}$. Two milliliters of each treatment were dispensed into 6 wells in multiple well plates (12 wells), and 5 individuals of $F$. taraikaensis were inoculated into each well. All treatments were incubated at $20^{\circ} \mathrm{C}$ and 30 $\mu$ mol photon $\mathrm{m}^{-1} \mathrm{~s}^{-1}$ with a $14 \mathrm{~h}: 10 \mathrm{~h}$ light-dark photo cycle. Motile individuals of F. taraikaensis were monitored over $4 \mathrm{~d}$ using a stereomicro-

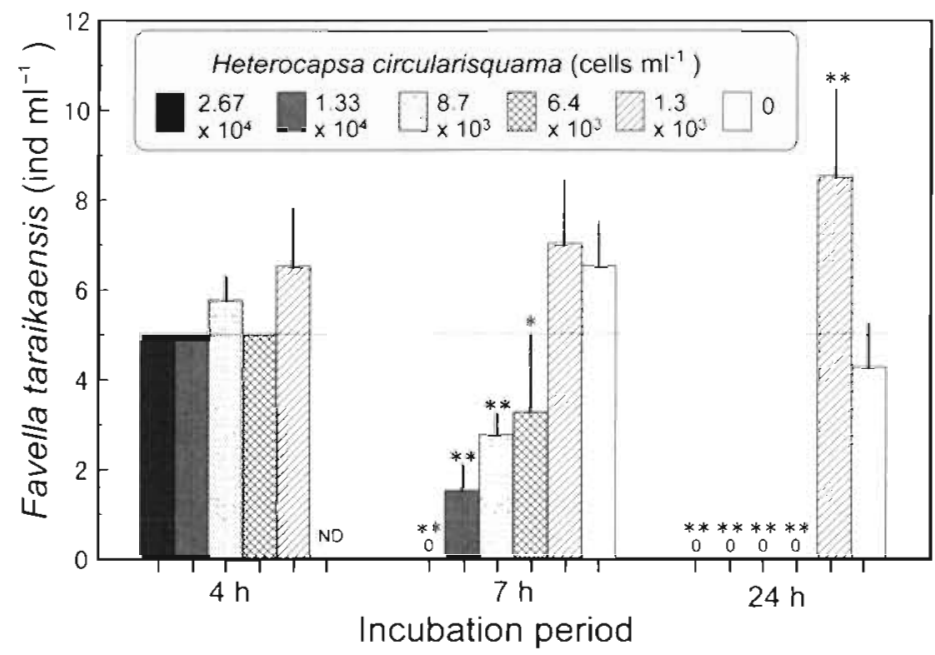

Fig. 1. Favella taraikaensis. Effect of the concentration of Heterocapsa circularisquama on survival. Vertical lines indicate standard deviation of the mean $(n=4) .{ }^{*} p<0.05, * * p<0.01$, significantly different from values at the no food treatment scope.

Observation of the interaction between Heterocapsa circularisquama and Favella taraikaensis cells. It is necessary to hold living ciliates in position to observe their behavior under the microscope. We used white vaseline for holding ciliates (Taniguchi \& Takeda 1988). Several individuals of Favella taraikaensis were washed with algal-free medium and transferred to a hole slide glass coated with white vaseline, which had been filled with a few drops of a dense suspension of Heterocapsa circularisquama (cell concentration: $>10^{5}$ cells $\mathrm{ml}^{-1}$ ). A cover slide was then placed over the vaseline ring. Some individuals of F. taraikaensis became stuck in the vaseline at times when this procedure was used. Although ciliates thus held could not move, their adoral membranelles continued to beat normally. The behavioral response of the membranelles of $F$. taraikaensis when exposed to $H$. circularisquama was observed and recorded using a VTR system attached to an inverted microscope as described above. We also observed the behavior of $F$. taraikaensis in response to $H$. triquetra in the same manner in order to compare it with the behavior observed in response to $H$. circularisquama.

\section{RESULTS}

Fig. 1 shows the growth/survival response of Favella taraikaensis at various concentrations of Heterocapsa circularisquama over $24 \mathrm{~h}$. The density of $F$. taraikaensis significantly decreased after $7 \mathrm{~h}$ of incubation with $\geq 6.4 \times 10^{3}$ cells $\mathrm{ml}^{-1}$ of $H$. circularisquama. The decrease occurred more rapidly with increasing concentrations of $H$. circularisquama. After $24 \mathrm{~h}, \mathrm{~F}$. taraikaensis had mostly died at concentrations of $\geq 6.4 \times 10^{3}$ cells $\mathrm{ml}^{-1}$ but increased at the concentration of $1.3 \times 10^{3}$ cells $\mathrm{ml}^{-1}$. A decrease under the no food treatment was not observed.

After 4 or 7 h of incubation, morphological changes in Favella taraikaensis were observed at a high concentration of Heterocapsa circularisquama $\left(2.86 \times 10^{4}\right.$ cells $\mathrm{ml}^{-1}$ ); some of the tintinnid cells swelled (Fig. 2B. C), or became spherical in shape after shedding their loricae (Fig. 2D). Abnormal mobility, i.e. backwards swimming behavior (Hansen 1989), was also observed. All the tintinnids finally lysed after being immobilized. The mean apparent lateral cell area of $F$. taraikaensis ( $\mathrm{n}=10$ ) was $3462 \pm 804 \mathrm{\mu m}^{-2}$ at the beginning of incubation but had significantly increased after $4 \mathrm{~h}$ of

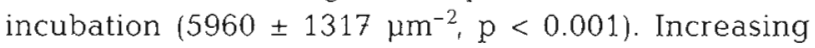
cell volume of $F$. taraikaensis evidently was not due to feeding because only a few auto-fluorescent particles were observed in the food vacuoles of swollen tintinnids.

Microscopic observation with the VTR system showed the characteristic interaction between Favella taraikaensis and Heterocapsa circularisquama. H. circularisquama cells frequently adhered to the AZM (adoral zone of membranelles) of $F$. taraikaensis (Fig. 3A). Apparently, this behavior was not part of the feeding process of $F$. taraikaensis because tintinnids finally rejected the adhered cells. The mean adhesion time of a $H$. circularisquama cell to the AZM was $63 \pm 66 \mathrm{~s}$ ( $n=20$ ), significantly longer than that of the non-toxic Heterocapsa triquetra $(0.4 \pm 1.1 \mathrm{~s}, \mathrm{p}<0.001)$. Direct contact of $H$. circularisquama cells with the cell surface around the oral plug of F. taraikaensis was observed during the adhesion process (Fig. 3B). 


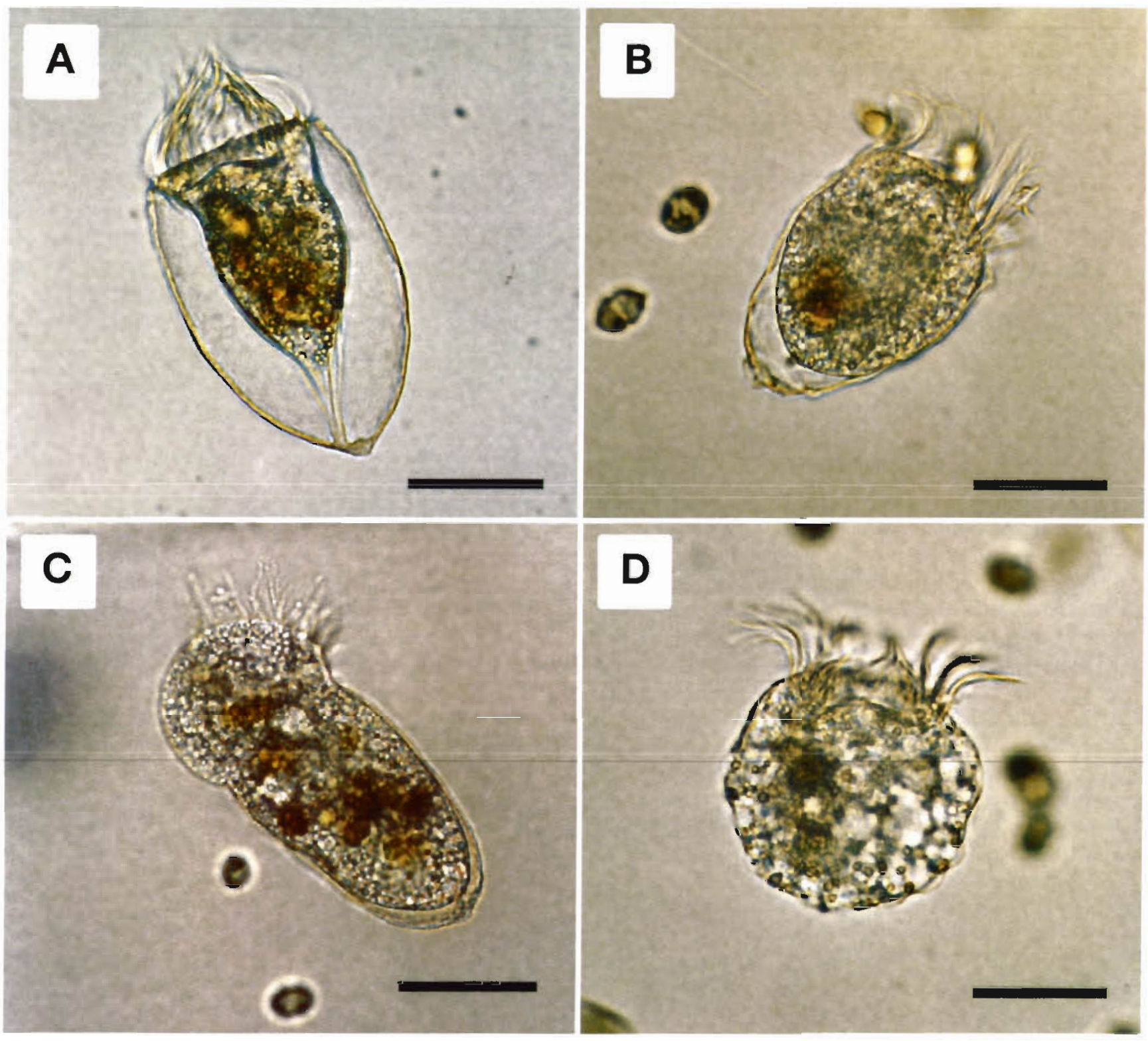

Fig. 2. Favella taraikaensis. Morphological changes caused by Heterocapsa circularisquama. (A) A normal individual (before the experiment); ( $B, C)$ swollen individuals (after 4 and $7 \mathrm{~h}$ of incubation, respectively); (D) a swollen naked individual (after $4 \mathrm{~h}$ of incubation). Scale bars $=50 \mu \mathrm{m}$

Fig. 4 represents the number of Heterocapsa circularisquama cells ingested by Favella taraikaensis as a function of the incubation period. The cell number of $H$. circularisquama cells ingested by $F$. taraikaensis generally increased for the first $60 \mathrm{~min}$. Ingestion at a concentration of $5.2 \times 10^{3}$ and $1.35 \times 10^{4}$ cells ml ${ }^{-1}$ was significantly higher than that at a concentration of $5.2 \times$ $10^{2}$ cells ml ${ }^{-1}$ after $10,20,40,60 \mathrm{~min}$ of incubation, but ingestion at the other times was not significantly different among the 3 different treatments ( $p \geq 0.05)$. These results indicate that during short-term incubations ( $\leq 60 \mathrm{~min}) F$. taraikaensis can feed on $H$. circular- isquama even at levels as high as $1.35 \times 10^{4}$ and $5.2 \times$ $10^{3}$ cells $\mathrm{ml}^{-1}$ and mortality of $F$. taraikaensis was not caused by starvation due to the rejection of $H$. circularisquama.

Fig. 5 shows the effect of the exudate from Heterocapsa circularisquama on the survival of Favella taraikaensis. Motile F. taraikaensis disappeared after $7 \mathrm{~h}$ of incubation in the dense suspension of $\mathrm{H}$. circularisquama, although the number of motile individuals between the other treatments was not significantly different at this time point. Mortalities in the addition of the exudate treatment and the control treatment simi- 

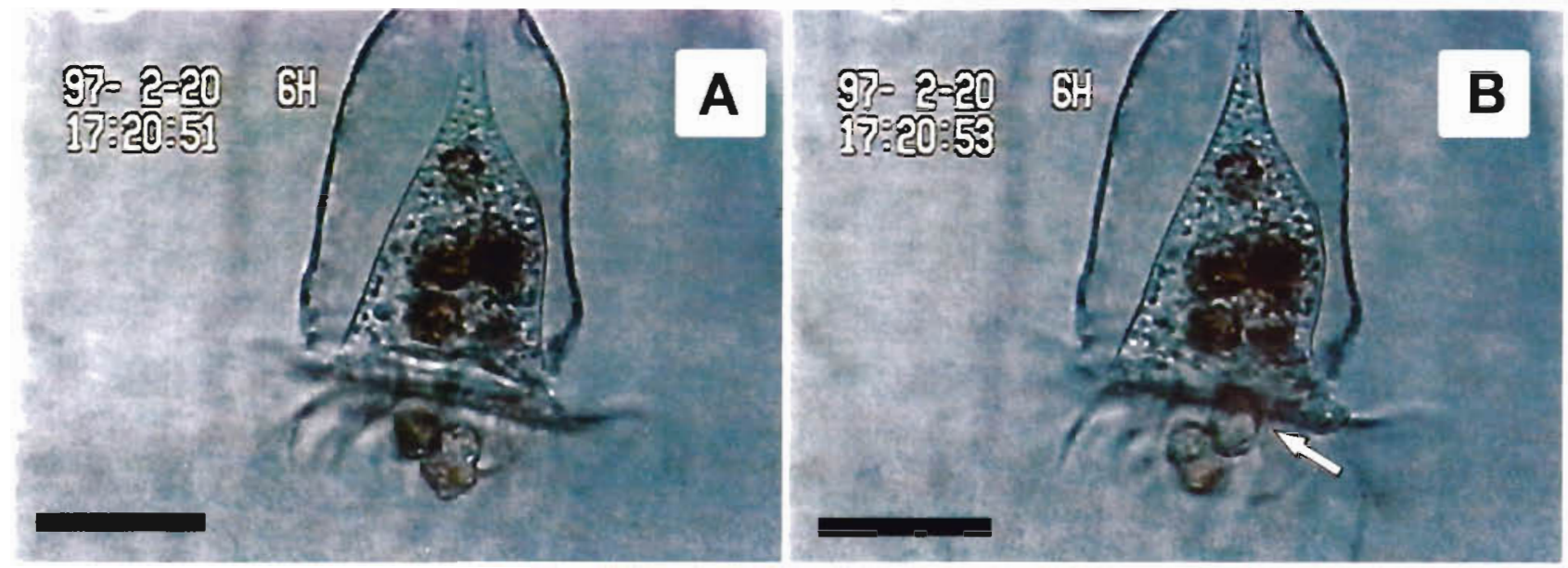

Fig. 3. Interaction between Favella taraikaensis and Heterocapsa circularisquama. (A) Adhesion of 2 cells of H. circularisquama to the adoral membranelles of $F$. taraikaensis; $(B)$ contact of the $H$. circularisquama cell with the cell surface around the oral plug of $F$. taraikaensis during the adhesion process (arrow). Scale bars $=40 \mu \mathrm{m}$

larly occurred after 48 to $72 \mathrm{~h}$ of incubation and were therefore assumed to be due to starvation. These results indicate that the $H$. circularisquama exudate does not enhance the mortality of $F$. taraikaensis.

\section{DISCUSSION}

A high concentration of phytoplankton causes a decrease of tintinnid growth at times even if the alga is not toxic (Verity 1985, Kamiyama 1997). However, it is evident that the retardation of growth rates is different from mortality. In the present study, Favella taraikaensis died more rapidly at the high concentrations of Het-

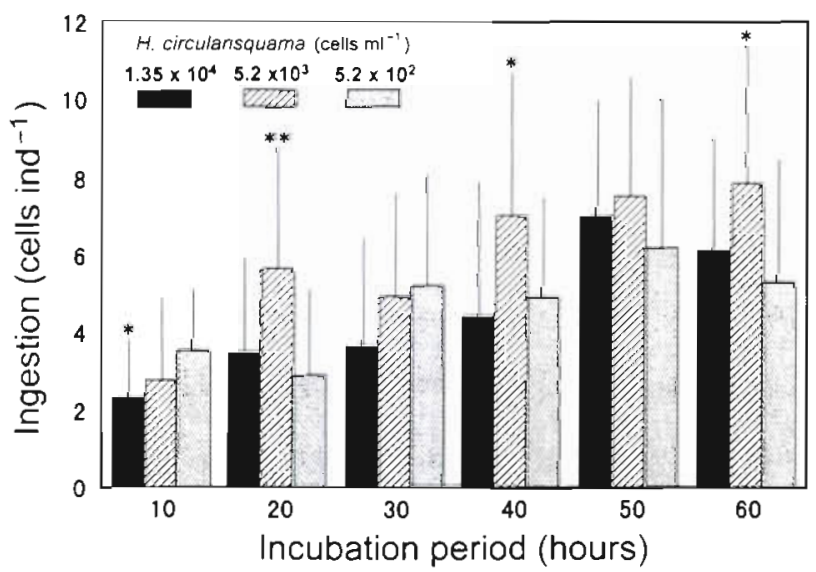

Fig. 4. Favella taraikaensis. Cell uptake as a function of incubation period and concentration of Heterocapsa circularisquama. Vertical lines indicate standard deviation of the mean $(\mathrm{n}=20$ to 24$) . " \mathrm{p}<0.05, " \mathrm{p}<0.01$, significantly different from the values at the algal concentration of $5.2 \times 10^{2}$ cells $\mathrm{ml}^{-1}$ erocapsa circularisquama than under no food conditions (Fig. 1), indicating that the decrease of $F$. taraikaensis was probably due to a toxic interaction with $H$. circularisquama. The reaction of $F$. taraikaensis to $H$. circularisquama is very characteristic. Hansen (1989) reported that toxic substances exuded from Alexandrium tamarense inhibited swimming behavior and the growth of Favella ehrenbergii. However, in the present study, the filtrate from a dense suspension of $H$. circularisquama did not influence the survival of $F$. taraikaensis (Fig. 5). Similarly, the alga-free medium of H. akashiwo (as Olithodiscus luteus), rejected as food by various zooplankton, did not influence the ingestion or growth of tintinnids and rotifers (Verity \& Stoecker

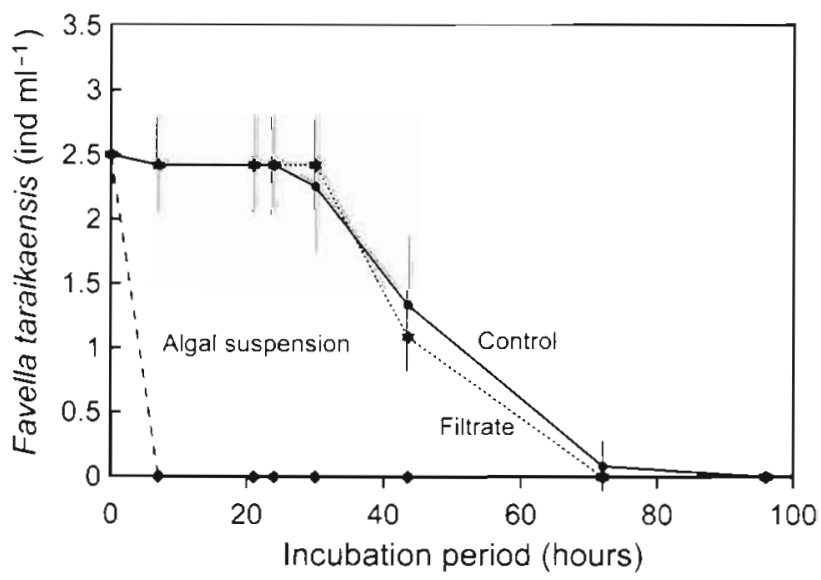

Fig. 5. Favella taraikaensis. Survival response to the suspension $(\downarrow)$ and filtrate (*) of Heterocapsa circularisquama. Algal concentration: $3.42 \times 10^{4}$ cells $\mathrm{ml}^{-1}$ for suspension and $1.37 \times$ $10^{5}$ cells $\mathrm{ml}^{-1}$ for filtrate. Control $(\bullet)$ is the result in fresh medium. Vertical lines (solid line: control; dotted line: filtrate) indicate standard deviation of the mean $(n=6)$ 
1982, Egloff 1986). However, F. taraikaensis usually avoids capturing $H$. akashiwo cells and rapidly ejects the cells from the peristomial cavity, if it accidentally captures them (Taniguchi \& Takeda 1988). This is evidently different from the phenomenon that F. taraikaensis could feed on $H$. circularisquama for a short period, irrespective of the concentrations.

There are 3 possibilities that may explain the toxic mechanism: toxicity derives from the intracellular components, the extracellular products or the cell surface. The most probable site of toxicity is considered to be on the cell surface of Heterocapsa circularisquama because of the following points. Favella taraikaensis could actively ingest $H$. circularisquama cells (Fig. 4 present study, Kamiyama 1997) and grew under low concentrations of this alga (Fig. 1), indicating that intracellular substances of the alga have no effect on the mortality of $F$. taraikaensis. The toxic substance may be largely insoluble with little of it dissolving into the surrounding seawater because the culture filtrate of $H$. circularisquama did not suppress the survival of F. taraikaensis, although there is a possibility that the toxic effect may be reduced once the substance is exuded from the cell due to decomposition. A characteristic attachment behavior of $H$. circularisquama to $F$. taraikaensis was observed, suggesting that a chemical substance existing on the cell surface of $H$. circularisquama is a probable cause of the mortality of $F$. taraikaensis due to cell contact.

The adhesion of Heterocapsa circularisquama to the AZM of Favella taraikaensis may be an important process in the mechanism of F. taraikaensis mortality. The attachment of $H$. circularisquama is probably irritating to F. taraikaensis. It appeared likely that abnormal behavior such as backwards swimming occurred in an attempt to brush off $H$. circularisquama cells. F. taraikaensis can usually feed on preferred food algae within $1 \mathrm{~s}$ (Taniguchi \& Takeda 1988). In the present study, the attachment of Heterocapsa triquetra cells to the AZM of $F$ taraikaensis occurred only momentarily. Long-term adhesion of $H$. circularisquama to the membranelles implies that $H$. circularisquama cells have a specific ability to attach to the AZM. Using a scanning electron microscope, adhesive substances were observed on the cell surface of $H$. circularisquama (Y. Matsuyama pers. comm.). Alternatively, there is a possibility that $F$ taraikaensis produces extracellular adhesive substances such as mucus when $H$. circularisquama cells make contact with the AZM of F taraikaensis. However, if this phenomena were important, it would occur irrespective of the algal concentrations and suppress tintinnid feeding at low concentrations of $H$. circularisquama, which is inconsistent with the results of this study, i.e. that $F$. taraikaensis can actively feed on $H$. circularisquama and grow at low concentrations of this alga.
The attachment of Heterocapsa circularisquama to the AZM may not be a key factor in causing the mortality of Favella taraikaensis because this behavior would have taken place during the feeding process when F. taraikaensis could actively feed on $H$. circularisquama. The toxicity of $H$. circularisquama cannot affect $F$. taraikaensis from the lateral and aboral direction because of the protection provided by the lorica. The main cause of mortality of F. taraikaensis is probably direct cell contact with the cytoplasm around the peristomial cavity or oral plug, as observed in this study.

Uchida et al. (1995) reported that Heterocapsa circularisquama kills another dinoflagellate, Gyrodinium instriatum, by cell contact. Further, the mortality of pearl oysters due to $H$. circularisquama was considered to be caused by direct contact of $H$. circularisquama with the body of oysters (Nagai et al. 1996, Matsuyama et al. 1997). In this study, mass mortaility of Favella taraikaensis under higher concentrations of $H$. circularisquama was probably caused by an increased incidence of cell contact. It is unknown at present whether the lethal effects of $H$. circularisquama on such organisms are caused by the same toxic substance. Further studies are necessary to identify the toxic substance, which is probably contained in the cell surface components.

As for the interaction between Heterocapsa circularisquama and other protists, the lethal effect of $H$. circularisquama may depend on the protection mechanisms of the protists; $H$. circularisquama can more easily influence naked organisms as compared to loricated organisms such as tintinnids. Considerable mortality of Favella taraikaensis at high concentrations of $H$. circularisquama (less than $7 \mathrm{~h}$ ) took longer than that of the naked flagellate Gyrodinium instriatum (less than 15 mini Uchida et al. 1995).

The many swollen or naked Favella taraikaensis became immobile and their feeding inactive, suggesting that physiological problems inside $F$. taraikaensis cells occurred. Toxic substances from Alexandrium tamarense and Gyrodinium aureolum make tintinnid ciliates swell and finally lyse (Hansen 1989, 1995), consistent with the response of $F$. taraikaensis to Heterocapsa circularisquama.

Based on the results from the present study and on previous findings (Kamiyama 1997), cells ingested by Favella taraikaensis probably do not cause the physiological problem observed in the tintinnid. Specifically, toxic substances of Heterocapsa circularisquama do not have an effect on $F$. taraikaensis in its food vacuoles. Lack of toxic effects in the food vacuoles implies that the toxicity effect is unstable against a pH shift or digestive intracellular enzymes in the food vacuole (Capriulo 1990). Toxicity of $H$. circularisquama for 
bivalves is due to a protein-like substance involving the outer cell components and its activity is easily stopped by chemical treatment with trypsin and sodium dodecylsulfate (Matsuyama et al. 1997).

In conclusion, the harmful effects of Heterocapsa circularisquama on Favella taraikaensis are assumed to be due to the following mechanism. Favella taraikaensis can effectively ingest $H$. circularisquama cells under pre-bloom concentrations. In this situation toxic substances do not have harmful effects on $F$. taraikaensis, because cell contact between the 2 organisms rarely occurs. With increasing concentrations of $\mathrm{H}$. circularisquama, the chances of adhesion to the AZM of $F$. taraikaensis increase, and F. taraikaensis are unable to brush away $H$. circularisquama cells from their AZM. When the concentration of $H$. circularisquama reaches $\geq 6400$ cells $\mathrm{ml}^{-1}$, cell contact between cell surfaces of $H$. circularisquama and $F$. taraikaensis causes $F$. taraikaensis to swell, become immobilized and finally lyse. Such a mortality process in ciliates due to direct contact with a dinoflagellate has not previously been reported. Understanding the harmful effects of $H$. circularisquama on their grazers is essential not only to analyze the mechanism of bloom formation and decay in nature but also to estimate the effects of this dinoflagellate on the function of microbial food webs as one major component of pelagic matter fluxes in coastal marine systems. For these purposes, further information on the interaction between $H$. circularisquama and zooplankton should be accumulated.

Acknowledgements. We thank Dr M. Maeda for his critical reading of the manuscript. Thanks are also due to Y. Matsuyama for giving us information on the morphological characteristics of Heterocapsa circularisquama and to Dr T Uchida for providing culture strains of $H$. circularisquama. This work was supported by a grant from the Environmental Agency of Japan.

\section{LITERATURE CITED}

Capriulo GM (1990) Feeding-related ecology of marine protozoa. In: Capriulo GM (ed) Ecology of marine protozoa Oxford University Press, New York, p 186-259

Egloff DA (1986) Effects of Olithodiscus luteus on the feeding

Editorial responsiblity: Otto Kinne (Editor),

Oldendort/Luhe, Germany and reproduction of the marine rotifer Synchaeta cecilia. J Plankton Res 8:263-274

Guillard RRL, Ryther JH (1962) Studies on marine planktonic diatoms. I. Cyclotella nana Hustedt, and Detonula confervacea (Cleve) Gran. Can J Microbiol 8:229-239

Hansen PJ (1989) The red tide dinoflagellate Alexandrium tamarense: effects on behaviour and growth of a tintinnid ciliate. Mar Ecol Prog Ser 53:105-116

Hansen PJ (1995) Growth and grazing response of a ciliate feeding on the red tide dinoflagellate Gyrodinium aureolum in monoculture and in mixture with a non-toxic alga Mar Ecol Prog Ser 121:65-72

Kamlyama T (1997) Growth and grazing responses of tintinnud clliates feeding on the toxic dinoflagellate Heterocapsa circularisquama. Mar Biol 128.509-515

Matsuyama $Y$, Nagai K, Mizuguchi T, Fujiwara M, Ishimura M, Yamaguchi M, Uchida T, Honjo T (1995) Ecological features and mass mortality of pearl oysters during red tides of Heterocapsa sp. in Ago Bay in 1992. Nippon Suisan Gakk 61:35-41 (in Japanese with English abstract)

Matsuyama Y, Uchida T, Honjo T (1997) Toxic effects of the dinoflagellate Heterocapsa circularisquama on clearance rate of the blue mussel Mytilus galloprovincialis. Mar Ecol Prog Ser 146:73-80

Nagai K, Matsuyama Y, Uchida T, Yamaguchi M, Ishimura M, Nishimura A, Akamatsu S, Honjo T (1996) Toxicity and $\mathrm{LD}_{50}$ levels of the red tide dinoflagellate Heterocapsa circularisquama on juvenile pearl oysters. Aquaculture 144 $149-154$

Stoecker D, Guillard RRL, Kavee RM (1981) Selective predation by Favella ehrenbergii (Tintinnial on and among dinoflagellates. Biol Bull (Woods Hole) 160:136-145

Stoecker DK, Silver MW, Michaels AE, Davis LH (1988) Obiigate mixotrophy in Laboea strobila, a ciliate which retains chloroplasts. Mar Biol 99:415-423

Taniguchi A, Takeda $Y$ (1988) Feeding rate and behavior of the tintinnid ciliate Favella taraikaensis observed with a high speed VTR system. Mar Microb Food Webs 3 $21-34$

Uchida T, Yamaguchi M, Matsuyama Y, Honjo T (1995) The red-tide dinoflagellate Heterocapsa sp. kills Gymnodinium instriatum by cell contact. Mar Ecol Prog Ser 118 301-303

Uye S, Takamatsu K (1990) Feeding interactions between planktonic copepods and red-tide flagellates from Japanese coastal waters. Mar Ecol Prog Ser 59:97-107

Verity PG (1985) Grazing, respiration, excretion, and growth rates of tintinnids. Limnol Oceanogr 30:1268-1282

Venty PG, Stoecker D (1982) Effects of Olisthodiscus luteus on the growth and abundance of tintinnids. Mar Biol 72 79-87

Yamamoto C, Tanaka Y (1990) Two species of harmful red tide plankton increased in Fukuoka Bay. Bull Fukuoka Fish Exp Stn 16:43-44 (in Japanese)

Submitted: July 17, 1997; Accepted: October 8, 1997

Proofs received from author(s): December 1, 1997 